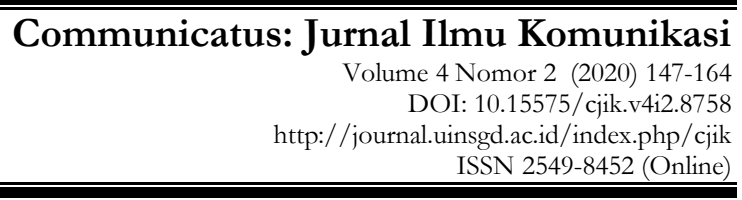

\title{
Analisis Pemanfaatan Vlog "Yossie-Dani" dalam Penyampaian Informasi Publik Pemerintah Kota Semarang
}

\author{
Martha Tri Lestari ${ }^{1^{*}}$ \& Lisa Aji Sasmita ${ }^{2}$ \\ 1,2 Telkom University \\ *email.marthadjamil@telkomuniversity.ac.id
}

\begin{abstract}
This study aims to determine how to convey information from the Semarang City government to the public based on the sources used, relevant to people's lives, delivery of information based on the latest facts and accountable information, proximity to the community, and the use of the $5 \mathrm{~W}+1 \mathrm{H}$ formula. This research uses descriptive qualitative research methods. The results showed that the Semarang City Government used YouTube and vlogs as a medium for delivering information to the public by creating vlog content "Yossie-Dani." There are several tricks in the vlog, such as utilizing the blooper concept, giving style editing in the form of sound effects and text effects. There are several news values in the Yossie-Dani vlog, namely popular sources, relevant to people's lives, delivery of information based on the latest facts and accountable information, proximity to the community, and the use of the $5 \mathrm{~W}+1 \mathrm{H}$ formula. By creating digital creative ideas in communicating, closeness will be built with the public so as to increase customer engagement with positive values.
\end{abstract}

Keywords : Public Information, Vlog, Youtube, News, Government.

\begin{abstract}
ABSTRAK
Penelitian ini bertujuan untuk mengetahui cara penyampaian informasi pemerintah Kota Semarang kepada publik berdasarkan narasumber yang digunakan, relevan dengan kehidupan masyarakat, penyampaian informasi berdasarkan fakta terbaru dan informasi dapat dipertanggungjawabkan, jarak kedekatan dengan masyarakat, serta penggunaan rumus $5 \mathrm{~W}+1 \mathrm{H}$. Penelitian ini menggunakan metode penelitian deskriptif kualitatif. Hasil penelitian menunjukkan bahwa, Pemerintah Kota Semarang menggunakan youtube dan vlog sebagai media penyampaian informasi kepada publik, dengan membuat konten vlog "Yossie-Dani". Ada beberapa trik dalam vlog tersebut seperti, memanfaatkan konsep blooper, memberikan style editing berupa sound effect dan text effect. Ada beberapa nilai berita di vlog Yossie-Dani, yaitu narasumber yang populer, relevan dengan kehidupan masyarakat, penyampaian informasi berdasarkan fakta terbaru dan informasi dapat dipertanggungjawabkan, jarak kedekatan dengan masyarakat, serta penggunaan rumus $5 \mathrm{~W}+1 \mathrm{H}$. dengan menciptakan ide-ide kreatif digital dalam melakukan komunikasi, maka akan terbangun kedekatan dengan publik, sehingga dapat meningkatkan customer engagement yang bernilai positif.
\end{abstract}

Kata Kunci : Informasi Publik, Vlog, Youtube, Berita, Pemerintahan

Diterima: Juli 2020 Disetujui: Oktober 2020 Dipublikasikan: Desember 2020 


\section{PENDAHULUAN}

Para pejabat pemerintah dituntut untuk mengembangkan kreativitas dan terus berinovasi dalam membangun dan meningkatkan komunikasi dengan publik, sehingga pemerintah mendapat kepercayaan masyarakatnya (Adi dan Mariani, 2016). Dalam membangun komunikasi dengan masyarakat, diperlukan media yang dapat menjembatani penyebaran informasi yang disampaikan pemerintah kepada masyarakat. Media yang tidak hanya bisa melakukan penyebaran informasi cepat, tetapi media yang bisa dipakai secara efektif dan efisien dan mampu dijangkau oleh seluruh elemen masyarakat.

Menurut Schechter saat ini media yang dipakai masyarakat mengalami perubahan seiring perkembangan teknologi, yaitu media konvensional (old media) menjadi media baru (new media). Media konvensional (old media) meliputi media cetak, radio, televisi, dan sebagainya. Keberadaan media konvensional ini mulai dirasakan tidak efektif lagi dipenggunakan sehingga media ini mengalami kematian (Gumelar, 2013: 7). Sementara media baru mulai ramai dipakai masyarakat, di antaranya media sosial.

Tidak dipungkiri media sosial mengalami perkembangan yang sangat pesat dan begitu popular di masyarakat. Dengan cepat pula media sosial ini menggantikan peran media tradisional yang lebih dulu hadir di masyarakat (Liu et al., 2019). Baik masyarakat perkotaan maupun masyarakat pedesaan, begitu akrab dengan media sosial.

Faktor yang mengakibatkan media sosial mengalami perkembangan cepat diantaranya adalah karena kebebasan masyarakat dalam mengakses berbagai konten di media sosial (David, Sondakh, \& Harilama, 2017). Isi dari media sosial lebih variatif, sajiannya cepat, dan masyarakat bisa lebih interaktif dengan media sosial.

Media sosial juga memberikan ruang gerak yang bebas bagi para penggunanya dalam mencari informasi yang dibutuhkan masyarakat, menyajikan hiburan dan informasi lainnya yang varitaf, dan mengakses yang tanpa mengenal batasan ruang dan waktu. Media sosial merupakan saluran yang berguna untuk mempublikasikan akun pribadi seperti riwayat, kegiatan sehari-hari maupun sebagai ruang menyampaikan pendapat yang membentuk suatu komunitas dalam dunia virtual (Nasrullah, 2014: 36).

Inilah yang menjadikan media sosial lebih diterima dan mengalami jumlah pengguna yang sangat cepat. Berdasarkan hasil survei APJII tahun 2017 bahwa pengguna media sosial di Inonesia meningkat tajam, yaitu 87,13\% (APJII, 2017). Dari jumlah pengguna yang semakin banyak, dengan beragam pengguna mulai dari kalangan muda dan tua, tentu saja kehadiran media sosial ini memberikan pengaruh yang besar terhadap masyarakat, termasuk pengaruh negatif. Misalnya saja pengaruh media sosial terhadap tingkat pidana narkotika sebesar kurang lebih $88 \%$ (Mardiana, 2018:109). 
Analisis Pemanfaatan Vlog "Yossie-Dani” dalam Penyampaian Informasi Publik Pemerintah Kota Semarang

Keberadaan media sosial juga memiliki pengaruh positif pada berbagai unsur kehidupan di masyarakat. Media sosial ini juga dimanfaatkan oleh para pejabat negara untuk kepentingan pribadi atau menopang kinerjanya. Di Amerika Serikat, beberapa tokoh publiknya telah menggunakan kelebihan dan fasilitas yang dimiliki media sosial, khususnya Youtube dan Web 2.0, sebagai media yang bisa mensosialisasikan diri, gagasan, dan untuk kampanye politik kepada para konstituennya (Hendricks \& Robert E. Denton, 2010). Tidak hanya politisi, para pejabat pemerintah pun terus menjaga komunikasi dengan publik menggunakan situs web dan media sosial pribadi (Andriana, 2013). Bahkan tidak hanya sekedar komunikasi dengan publik, tetapi juga para pejabat dan pemerintah ini berusaha merangkul dan melibatkan publik dalam rangka mensukseskan program dan kebijakan dengan membuat akun media sosial bahkan website pribadi, seperti yang dilakukan Gubernur Jawa Barat, Ridwan Kamil, yang tidak hanya membagikan konten-konten seputar program dan kebijakannya, akan tetapi berbagai gagasannya dalam membangun Jawa Barat terus disebarluaskan di media sosial yang dikelolanya (Wulansari, 2018).

Ada beragam platform di media sosial yang senantiasa dimanfaatkan oleh masyarakat dan para pejabat pemerintah, seperti: youtube, facebook, instagram, twitter, skype, blog, dan linkedin. Hadirnya media sosial dengan berbagai fungsi yang berbeda-beda, masyarakat dan pemerintah bisa menggunakannya sesuai dengan kebutuhannya, mulai dari chatting, mengunggah gambar, mengunggah video, menulis pendapat atau ide ke dalam tulisan, bahkan berkomunikasi melalui video di Youtube.

Khusus Youtube, yang merupakan media dengan memanfaatkan video sebagai media dalam penyampaian pesan yang dapat diandalkan. Youtube diciptakan sebagai media pencarian informasi yang memanfaatkan video dan dapat ditonton secara gratis, mengunggah video, dan membagikannya ke seluruh dunia (Baskoro, 2009: 58; Izzah dan Hadi, 2018).

Pengguna dapat mengakses youtube dari berbagai belahan dunia tanpa mengenal ruang dan waktu, sehingga pengguna youtube dapat saling terkoneksi dalam mengkonsumsi layanan youtube sehingga youtube menjadi pilihan utama masyarakat di Indonesia. Youtube di Indonesia menempati posisi pertama sebagai media sosial yang paling disenangi. Jumlah masyarakat Indonesia yang mengakses Youtube 55.9 juta (43\%) dari total 130 juta pengguna media sosial (Haryanto, 2018). Berbeda dengan hasil survei yang dilakukan Jejak Pendapat App, bahwa masyarakat Indonesia $88 \%$ menonton vlog di Youtube Jakpat, 2018). Jumlah yang lebih besar dibanding hasil survei Haryanto.

Youtube bisa menjadi media untuk publikasi karya masyarakat secara audio visual, dan bisa interaktif antara produsen konten, yang dikenal dengan vlogger, dengan para penonton selaku penerima konten. Dibandingkan dengan media sosial jenis blog yang lebih rawan dengan anonimitas antara pembuat dan 
konsumen kontennya (Aqil \& Fahri, 2018; Liu et al., 2019; Mahameruaji et al., 2018). Konten vlog dapat dibagikan dalam waktu yang singkat bahkan bersifat real-time (Earnshaw, 2017). Dan vlog media komunikasi yang menggabungkan antara video dan web sehingga pesannya akan lebih menarik, dan menghibur (Priana, 2017).

Pemerintah sebagai vlogger dapat membentuk komunitas, dan komunitas ini bisa juga menjadi pengisi vlog pemerintah (Gannon \& Prothero, 2018). Selain itu, melalui konten vlog pula, pemerintah akan mendapatkan respon, baik secara sosial maupun moral dari masyarakat yang bisa jadi tidak kenal satu persatunya oleh pemerintah (Gibson, 2016). Atau juga vlog milik pemerintahan bisa juga dijadikan sebagai media yang bisa menampung dukungan masyarakat, atau sebagai media kehumasan pemerintah. Selain itu, informasi yang disampaikan langsung pemerintah melalui vlog, dapat memberantas hoaks yang tersebar di masyarakat (Sugiono \& Irwansyah, 2019: 115).

Hasil penelitian dari (Graham \& Avery, 2013) mengenai Government Public Relations and Social Media: An Analysis of the Perception and Trends of Social Media use at the Local Government Level menunjukan bahwa, penggunaan media sosial yang dipilih dalam dunia pemerintahan yang digunakan sebagai alat kehumasan dalam melayani fungsi demokrasi, partisipasi, dan transparansi kegiatan yang ada dalam pemerintahan diindikasikan belum maksimal dalam penggunaan media sosial yang dilakukan oleh pemerintah, juga pemerintah tidak mempertimbangan penggunanya dalam mengkonsumsi informasi tersebut. Dalam penelitian ini pemerintah yang menjadi subjek penelitian menggunakan Facebook dan Twitter sebagai kanal penyampaian informasi publiknya. Adapun persamaan dengan penelitian yang dilakukan oleh kami sebagai tim peneliti adalah dilihat dari sisi kebutuhan penyampaian informasi publik dari pemerintah kepada publik yang sama-sama menggunakan kanal media sosial dengan platform yang berbeda. Dengan adanya penelitian yang sudah teruji sebelumnya maka dalam hal penelitian dengan topic serupa dapat dilakukan pada instansi pemerintahan lain yang berada di kota-kota lainnya, bukan hanya saja pemerintah kota namun pemerintah daerah lainnya yang harus sudah mulai melek akan strategi komunikasi publik dengan menggunakan media digital

Kualitas penyampaian informasi pemerintah sangat penting sehingga pemerintah harus betul-betul dapat memproses, menyaring dan menghasilkan informasi yang tidak hanya kredibel dan dapat dipertangungjawabkan, tetapi juga menarik dan bisa mengajak masyarakat untuk terlibat aktif. Dan di antara pemerintahan yang sudah melakukannya ialah Pemerintah Kota Semarang. Melalui Dinas Komunikasi Informatika (Diskominfo) Kota Semarang, Pemerintah Kota Semarang berusaha mengikuti perkembangan tren, yaitu melakukan tugasnya dalam penyampaian informasi kepada masyarakat Kota Semarang dengan menggunakan video blogging (vlog) yang bernama "Yossie-Dani". 
Analisis Pemanfaatan Vlog "Yossie-Dani” dalam Penyampaian Informasi Publik Pemerintah Kota Semarang

Dengan menggunakan paradigma konstruktivis, dimana paradigma ini melihat adanya realitas atau kebenaran bersifat tidak tunggal. Realitas itu didapatkan atau diciptakan oleh individu yang berada dalam kelompok tertentu melihat dari asumsi atau interpretasi individu tersebut (Morrisan, 2019:59). Dan metode yang digunakan deskriptif, yaitu suatu bentuk metode dalam penelitian yang dapat menjelaskan mengenai fakta, objek, aktivitas, proses, dan manusia secara alamiah pada waktu sekarang atau dalam waktu yang lampau, dimana responden masih mengingatnya (Prastowo, 2011:203), maka penelitian ini bertujuan untuk menjelaskan bagaimana penyampaian informasi yang dilakukan Pemerintah Kota Semarang yang menggunakan vlog sebagai media komunikasi.

\section{HASIL DAN PEMBAHASAN}

\section{Narasumber dan Relevansi dengan Kehidupan Masyarakat}

Vlog yang digunakan Pemerintah Kota Semarang dengan sebuatan "Yossie-Dani". $V \log$ ini merupakan salah satu media penyampaian informasi Kota Semarang yang memanfaatkan youtube sebagai sarana dalam memberikan informasi, edukasi, dan kegiatan liputan yang berhubungan dengan Pemerintah Kota Semarang dengan kemasan yang santai, ringan, dan dibumbui lelucon atau humor. V $\log$ "Yossie-Dani” ini dipandu oleh 2 orang yang merupakan pegawai dari Diskominfo Kota Semarang, yaitu Yosia Yogaswara dan Dani Nugroho, dan sebagai pencetus konten $v \log$ "Yossie-Dani” Bapak Muhammad Ivan.

Awal mula lahirnya konten ini ialah melihat adanya kebosanan dalam penyediaan informasi yang kurang menarik di pemerintahan, khususnya Pemerintah Kota Semarang, dan sebagai upaya mengikuti perkembangan zaman atau tren yang sedang berkembang, sehingga masyarakat dapat dengan mudah memahami informasi melalui bentuk-bentuk strategi konten kreatif dan unik.

Apa yang dilakukan Pemerintah Kota Semarang dengan membuat vlog yang kemudian di share di Youtube dan Web 2.0, dinilai tepat, karena vlog bisa dengan efektif dijadikan media mensosialisasikan gagasan pemerintah yang kemudian dishare kepada para masyarakat (Hendricks \& Robert E. Denton, 2010). Selain sebagai sarana publikasi, vlog yang dimiliki Kota Semarang juga bisa sebagai ruang menyampaikan pendapat dari masyarakat, sekaligus sebagai wadah tempat berkumpulnya masyarakat di dunia virtual (Nasrullah, 2014: 36; Wolf, Sims \& Yang, 2018).

Adanya vlog ini, berarti Pemerintah Kota Semarang sudah membuat ruang publik di dunia maya, yang bisa dijadikan media dalam menampung aspirasiaspirasi masyarakat. Dengan demikian masyarakat merasa dilibatkan dalam proses pembangunan di Kota Semarang.

Penggunaan vlog oleh pemerintah Kota Semarang merupakan di lembaga pemerintahan yang masih menggunakan media-media konvensional. Sementara zaman sudah berubah dan berbeda. Pemerintah Kota Semarang telah melakukan 
berbagai kreatvitas dan inovasi dalam berkomunikasi antara pejabat pemerintahan dengan masyarakatnya. Pilihan vlog dinilai tepat, karena vlog merupakan media informatif yang dinikmati oleh berbagai kelompok dan semua usia (Purwadi, P., Novianty, A., Deden, N., Lestari, 2017). Hal sama juga dikatakan Herman (2017) bahwa strategi komunikasi yang efektif salah satunya menggunakan media sosial. Apalagi sekarang di era millenial hampir semua orang akrab dengan gadget dan on line.

Konten vlog Yossie-Dani cukup beragam, mulai dari yang bernuansa pemerintah sampai hal-hal sederhana yang diambil dari keseharian masyarakat. Konten dibuat dekat dan sesuai dengan keadaan masyarakat Semarang. Terutama program dan kebijakan-kebijakan pemerintah yang harus disosialisasikan kepada masyarakat, sehingga masyarakat Kota Semarang mengetahui program dan kebijakan pemerintah. Di antara konten yang sering dibuat dan di share ialah kuliner, grebek pasar tradisional, kunjungan ke sekolah-sekolah, grebek instansi dan acara-acara seputar Kota Semarang lainnya.

Menurut Harsono (dalam Panuju, 2018:86), Pemerintah Kota Semarang sudah sesuai dengan track sebagai komunikator dan menyampaikan pesan-pesan ke publik melalui vlog "Yossie-Dani" kepada masyarakat. Adapun isi pesanpesannya bebas tidak hanya pada satu bidang, bisa tentang politik, sosial, ekonomi, budaya, dan yang lainnya.

Tidak ketinggalan juga kalangan muda di Kota Semarang dijadikan target yang diberi pesan-pesan melalui vlog Kota Semarang. Menurut Yosia Yogaswara, bahwa "Konsep yang diusung dari "Yossie-Dani" dapat memberikan informasi yang anak muda banget dan mengikuti tren, namun masih dalam batas wajar dan mengikuti kaidah pemerintahan".

Pemerintah Kota Semarang tidak membatasi segmen penonton atau orang yang bisa menikmati vlog ini. Semua usia dijadikan target termasuk anak-anak muda sebagai generasi penerus di masa mendatang. Sebagaimana tujuan dari vlog sebagai pembentuk tiga jenis identitas, yaitu identitas budaya, identitas sosial dan identitas pribadi yang lekat dengan budaya anak muda (Sari, 2018:157).

Pengelola vlog Yossie-Dani yang mewakili Pemerintah Kota Semarang yang juga memprioritaskan segmen kalangan remaja merupakan strategi yang tepat, karena konten-konten di $v \log$ seringkali menjadi konten-konten yang digemari anak-anak muda. Tidak aneh kalau hasil survey Jejak Pendapat App menunjukkan bahwa $77 \%$ penonton vlog adalah usia 29 tahun ke bawah (Jakpat, 2018).

Vlog "Yossie-Dani" memanfaatkan konsep blooper. Pada aturan delapan detik vlog "Yossie-Dani" menggunakan konsep blooper yang berisi kesalahankesalahan yang terjadi selama proses shooting berlangsung. Durasi pada blooper dalam vlog "Yossie-Dani" memiliki waktu yang berbeda-beda, sehingga pada aturan delapan detik masih menampilkan blooper. 
Analisis Pemanfaatan Vlog "Yossie-Dani” dalam Penyampaian Informasi Publik Pemerintah Kota Semarang

Blooper ini digunakan agar penonton tidak merasa tegang dan merasa penasaran karena saat awal video diputar, isi dari blooper menampilkan hal-hal yang lucu, kejailan host dalam bebind the scene tersebut. Selain itu penggunaan kosa kata yang gagap, sering ditampilkan dengan menambahkan tulisan-tulisan dalam visualnya.

Blooper ini bertujuan untuk memberikan kesan ke-khas-an terhadap vlog "Yossie-Dani", dan hiburan yang dapat memberikan bumbu-bumbu lucu di setiap perilaku host "Yossie-Dani". Vlog "Yossie-Dani" ingin memberikan hiburan melalui karakter yang dibentuk dalam pembawaan host- nya dalam menyampaikan informasi yang dikemas dengan ringan, dan dapat diterima oleh seluruh kalangan masyarakat.

Penggunaan blooper di dalam vlog Yossie-Dani merupakan kolaborasi yang kreatif, sehingga konten $v \log$ Yossie-Dani ini tidak hanya berisi pesan-pesan yang informatif, tetapi juga ada unsur entertainmentnnya (Priana, 2017). Tidak heran kalau penonton atau masyarakat yang melihat konten-konten vlog Yossie-Dani merasa terhibur dan terus menantikan konten-konten yang baru lainnya.

Tanpa disadar, Pemerintah Kota Semarang sendiri tidak mengetahui konten yang dibuat oleh tim "Yossie-Dani", menjadi konten yang ditunggutunggu publik. Padahal tidak ada rencana yang matang, riset terlebih dahulu sebelum membuat konten. Dalam proses penggarapannya mengalir saja. Tim kreatif "Yossie-Dani" menilai adanya respon positif dan adanya publik yang loyal setia menanti konten-konten, merupakan bonus dari upaya untuk mengembangkan diseminasi terhadap publik.

Pemerintah Kota Semarang melalui Diskominfo Kota Semarang, melakukan kegiatan ini begitu normatif. Mereka hanya melakukan pembuatan konten vlog dan menyebarluaskan ke youtube, ketika sudah dishare ke youtube mereka tidak mencoba untuk mengevaluasi, melihat dampak, apalagi sampai melakukan pendalaman konten atau upaya-upaya pengembangan konten.

Host vlog "Yossie-Dani" tidak menyampaikan pencitraan mengenai kelebihan konten, yang dilakukan secara berulang dalam vlog tersebut. Mereka menganggap bahwa penyampaian yang menampilkan pencitraan akan memberikan dampak yang negatif kepada instansi, yaitu Pemerintah Kota Semarang, sehingga informasi yang disampaikan tidak mengandung pencitraan dan dibuat secara fakta dengan pembuatan alur yang spontan tanpa menggunakan pedoman atau teks, namun dalam aturan yang jelas dan tidak mengandung sara dan kata-kata negatif.

\section{Informasi berdasarkan fakta terbaru dan dapat dipertanggungjawabkan}

Pembuatan vlog Kota Semarang yang tidak dijadikan media pencitraan pemerintah merupakan langkah yang tepat. Tetapi tetap berorientasi pada produk atau tujuannya membuat karya yang bagus dan bermanfaat untuk masyarakat. Tentu akan berbeda dengan tujuannya pencitraan. Kalau tujuannya 
pencitraan maka hal-hal yang negative, kurang bagus, akan diubah menjadi konten yang baik padahal tidak sesuai dengan realitasnya. Tetapi ketika konten apa adanya dengan tujuan publikasi semata, maka masyarakatpun akan mengapresiasi lebih. Berbeda kalau pencitraan ketika masyarakat tahu hal yang sesungguhnya, maka masyarakat akan kecewa dan dampaknya bisa tidak percaya pada pemerintah. Jadi tetap focus pada membuat konten yang bagus. Karena konten vlog dari pejabat pemerintahan yang berkualitas, secara tidak langsung akan mengangkat citra lembaga dari penilaian masyarakat. Inilah metode dalam mengkomunikasikan brand dan nilai dari suatu lembaga di media on line (Martinus \& Chaniago, 2017).

Pembuatan materi dalam vlog "Yossie-Dani" bersifat fleksibel, briefing dilakukan dengan santai dan hanya dilakukan untuk memberikan informasi kepada tim lain untuk memberikan penjelasan terhadap materi yang diangkat untuk pembuatan vlog. Konten yang biasa, bisa berupa informasi pemerintahan Kota Semarang dan seputar Kota Semarang, namun informasi yang diangkat bersifat everlasting, yaitu informasi yang dibuat dan disajikan di dalam vlog tidak termakan oleh zaman. Konten-kontennya tidak mudah basi dan bisa bertahan lama.

Namun dengan upaya yang dilakukan tim "Yossie-Dani" dalam penyampaian informasi pada saat closing video, tidak memperintahkan penonton untuk melakukan aksi sebagai wujud timbal balik kepada Pemerintah Kota Semarang, seperti memberikan komentar, subscribe, like, dan share postingan vlog. Pemerintah Kota Semarang melalui vlog "Yossie-Danie" hanya memberikan informasi kepada masyarakat, tidak untuk mencari hal-hal tertentu lainnya.

Justru tanpa ajakan, seruan, dan intruksi apa pun dari pesan yang ada di setiap konten vlog Yossie-Dani, malah membuat sikap berbeda dari masyarakat selaku khalayak dari vlog ini. Karena masyarakat merasa tidak digurui, tidak dipaksa, tetapi konten yang dibuatkan tim vlog bermanfaat untuk masyarakat. Tidak heran kalau masyarakat malah tidak hanya apresiatif, tetapi juga terlibat aktif. Konten vlog Yossie-Dani dalam Youtube memiliki pengaruh yang kuat terhadap pembentukan sikap para penggunanya, dalam hal ini masyarakat Semarang (David, Sondakh dan Harilama, 2017).

Kalau pun ada perencanaan dalam pembentukan $v$ log, tim mulai merancang dan merumuskan materi $v \log$ h-2. Ketika membuat langsung shooting saja sehingga tidak ada penyusunan materi konten yang terjadwal pada periode tertentu. Pembuatan ide materi konten vlog juga datang dari berbagai pihak, tidak hanya tim dari "Yossie-Dani".

Karena sudah mulai menyebar dan banyak diketahui akan popularitas vlog Yossie-Dani, sehingga membuat pihak atau instansi lain yang memberikan masukan, terhadap pengangkatan materi atau issue untuk diliput oleh tim vlog Yossie-Dani. Tetapi instansi lain itu masih di lingkungan Pemerintah Kota 
Analisis Pemanfaatan Vlog "Yossie-Dani” dalam Penyampaian Informasi Publik Pemerintah Kota Semarang

Semarang dan beberapa masyarakat Semarang sendiri.

Beberapa saran dan masukan dari luar pemerintah Kota Semarang, sesekali diterima dan dibuatkan sesuai usulannya. Misalnya usulan membuat kontenkonten yang diinformasikan kepada masyarakat seputar kegiatan-kegiatan yang dilakukan para pejabat publik Kota Semarang, yang dilakukan di lingkungan Balaikota Semarang. Karena masyarakat juga berhak mengetahui kegiatan yang dilakukan pemerintah, agar Pemerintah Kota Semarang juga mendukung akan upaya pemerintah untuk memberi contoh dan menjaga transparansi yang jelas mengenai kinerja instansi pemerintahan secara luas.

Konten vlog selain bisa tentang opini mengenai berbagai topik yang aktual di masyarakat, juga bisa menceritakan berbagai kegiatan sehari-hari, atau juga menampilkan monolog individu (David et al., 2017; Raby, Caron, ThéwissenLeBlanc, Prioletta, \& Mitchell, 2018).

Durasi video pada vlog "Yossie-Dani" antara lima sampai tujuh menit. Karena kalau terlalu lama bisa menjemuhkan dan tidak dibagikan secara real time (Earnshaw, 2017). Penetapan durasi dalam vlog "Yossie-Dani" didasarkan pada hasil briefing tim "Yossie-Dani", dan telah menjadi kesepakatan dari atasan Pemerintah Kota Semarang. Sebagaimana dikatakan Schmittauer (2018:2), bahwa vlog adalah blog yang lebih banyak berisi video daripada teks atau gambar. Dan vlog Yossie-Dani kontennya menggunakan video dengan tema yang variative.

Alasannya ialah karena ketika menggunakan video, maka kontennya akan memiliki kepekaan yang sangat tinggi. Terutama dalam hal kejelasan pesan yang menggunakan audio-visual. Kalaupun terjadi kesalahan kedua hal tersebut dapat dipastikan penonton lebih jelas mengetahui kesalahan yang dari segi suara dan tampilannya.

Tim ketika menggarap vlog ini seringkali menggunakan kamera Digital Single Lens Reflex (DSLR), action camera, clip on, dan recorder. Tim vlog Yossie-Dani tidak menggunakan kamera dengan lighting yang lengkap dan representatif untuk sebuah pengambilan gambar. Cukup sederhana, yang penting ada audio-visual yang bisa mengemas pesan-pesan yang sesuai harapan tim dan bisa memuaskan masyarakat.

Kemudian cara mempertahankan fokus masyarakat dalam melihat vlog "Yossie-Dani" di youtube, tim "Yossie-Dani" membuat style editing yang dapat memberikan suasana video yang tidak monoton, seperti memberikan sound effect, text effect dan transisi editing dalam penggabungan atau pemotongan antara scene satu dengan scene yang lainnya.

Inilah alasan kenapa konten vlog Yossie-Dani seringkali dikomentari dengan komentar yang beragam, menjadi bahan diskusi ataupun perdebatan secara interaktif di youtube. Karena memang vlog bisa memfasilitasi keingian seperti ini (Mahameruaji et al., 2018).

Sebelum melakukan peliputan, tim "Yossie-Dani" sebelumnya tidak 
memberikan daftar pertanyaan kepada narasumber sebagai bentuk persiapan yang dilakukan narasumber untuk menjawab pertanyaan dari host "Yossie-Dani", sehingga jawaban yang didapatkan oleh tim "Yossie-Dani" adalah jawaban yang murni tanpa ada yang di buat-buat.

Alur dalam penyampaian jawaban dalam vlog "Yossie-Dani" dapat dijelaskan pada bagan sebagai berikut:

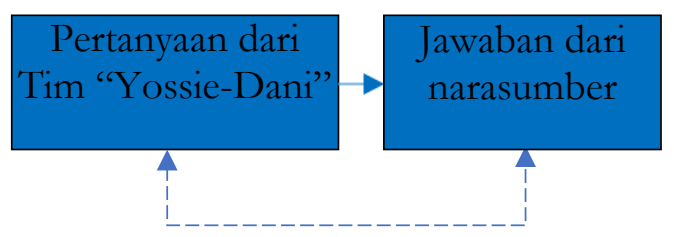

Sumber: Diolah dari berbagai sumber

Gambar 1. Alur dalam memberikan jawaban oleh narasumber dan host

Bagan di atas merupakan alur dalam memberikan jawaban oleh narasumber dan host pada vlog "Yossie-Dani". Host "Yossie-Dani" memberikan pertanyaan kepada narasumber mengenai pertanyaan tertentu, kemudian narasumber memberikan jawaban atas pertanyaan yang diberikan oleh host, setelah itu host menjelaskan dan memberikan tanggapan kembali terhadap jawaban yang telah diberikan oleh narasumber.

Sumber berita dalam vlog "Yossie-Dani" didapatkan dari narasumber, atau pihak yang melaksanakan atau berkepentingan dalam program dan kegiatan secara langsung. Tim "Yossie- Dani" tidak menggunakan referensi-referensi dari media lainnya, karena informasi yang telah didapatkan sudah terpercaya dan akurat. Apabila menggunakan media lainnya informasi yang didapatkan sudah tidak relevan dalam waktu tertentu, sehingga informasi tersebut mengacu kepada waktu yang terjadi pada waktu saat ini.

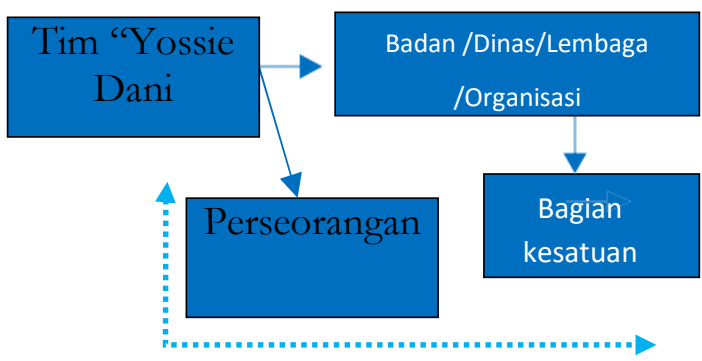

Sumber: Diolah dari berbagai sumber

Gambar 2. Alur koordinasi dalam memberikan informasi

Bagan tersebut merupakan alur koordinasi dalam memberikan informasi 
yang memang bersumber pada pihak- pihak yang dapat dipastikan akan kebenaran informasi yang disebarluaskan melalui media sosial youtube dalam bentuk vlog "Yossie-Dani". Sumber berita merupakan pihak yang dapat menjelaskan mengenai jawaban dari topik yang menjadi pembahasan. Sumber berita dapat juga didapatkan atau berasal dari seseorang yang kredibel dan dianggap kompeten di bidangnya, dari internet atau media lainnya (Wendratama, 2017: 38).

Selain itu, tim vlog Yossie-Dani juga memperhatikan hal-hal prinsip dalam pembuatan vlog untuk di youtube, yaitu: mengutamakan subjek dengan memperhatikan momen pertama dalam menampilkan video karena ini yang menjadi kesan pertama penonton. Inilah yang menentukan keputusan masyarakat untuk melanjutkan menonton video hingga selesai atau tidak. Membuat publik setia dengan tayangan vlog. taat pada aturan 8 detik pertama sebagai kesan yang sangat kritis dalam menentukan keputusan publik untuk melanjutkan hingga akhir video. Tidak berorientasi pada pencitraan. Konten yang dermawan. Mempertahankan publik agar tetap menonton tayangan video dengan fokus terhadap tayangan (Schmittauer, 2018: 84).

\section{Jarak Kedekatan Dengan Masyarakat}

Bahasa yang digunakan di vlog Yossie-Dani didominasi oleh Bahasa Indonesia, dan pada kesempatan tertentu host "Yossie-Dani" menyampaikan informasi dalam vlog menggunakan Bahasa Jawa. Ketika kebanyakan menggunakan Bahasa Indonesia akan banyak yang menonton vlog ini, meskipun tidak dari Semarang, sehingga jumlah orang yang melihatnya semakin banyak. Adapun sesekali menggunakan Bahasa Lokal atau Bahasa Jawa yang mayoritas digunakan oleh masyarakat, juga memiliki nilai plus. Penggunaan bahasa lokal tersebut dimaksudkan untuk memperjelas makna, dan agar terjalin kedekatan antara pemerintah yang diwakili vlog dengan masyarakat. Selain itu agar tidak punah bahasa lokal, dan syukur-syukur bisa membantu dalam mempopulerkan Bahasa Jawa. Di samping juga ketika menggunakan Bahasa lokal maka ada kedekatan yang tidak didapatkan dari orang luar Jawa.

Dalam penggunaan kata-kata tertentu, terutama Bahasa Indonesia seringkali dicampur dengan menggunakan bahasa Jawa yang menjadi kata-kata keseharian masyarakat yang menonton. Namun penggunaan kata-kata tersebut masih dalam kaidah yang baik dan tidak menggandung unsur sara.

Pengaturan gaya bahasa yang digunakan bersifat semi formal, dan tidak ada aturan yang terstruktur di dalam brief untuk mengatur gaya bahasa dalam vlog "Yossie-Dani". Kejelasan penyampaian informasi melalui visual, menggunakan gaya editing yang memanfaatkan font effect dibagian kata-kata pengucapan yang tidak terdengar jelas, atau ketika host menerangkan istilah-istilah tertentu.

Penggunaan closing dalam vlog "Yossie- Dani" belum memiliki konsistensi antara satu vlog dengan vlog yang lainnya, yang digunakan dalam penutupan vlog 
yaitu: tips dan trik, penutupan dengan pamit undur diri, dan bumper out. Closing menjadi bagian yang sangat penting sebagai pesan terakhir untuk menyimpulkan seluruh isi dalam vlog. Sering kali penonton akan memberikan perhatian yang lebih terhadap bagian terkahir ini.

Menurut Muhammad (2017:203) ada beberapa hal yang dapat meningkatkan kualitas penyampaian komunikasi kepada publik, yaitu kontak mata dengan tim vlog atau host banyak melihat kamera, karena kamera wakil dari pata penonton atau masyarakat, memperhatikan vokalik atau kecepatan dalam berbicara nada dan irama suara, serta penekanan pada kata-kata tertentu menjadi hal yang penting dalam menjelaskan pesan komunikasi. Namun dalam pengambilan gambar atau penampilan, diupayakan sealamiah mungkin agar tidak tegang atau serius.

\section{Menggunakan Rumus 5W+1H}

Meskipun sederhana konten-konten yang ada dalam vlog Yossie-Dani pun merujuk pada konten yang berbasis pada berita. Informasi ringan, bermanfaat, dan mengandung nilai berita seputar Kota Semarang. Seperti yang dikatakan Sumadiria (2017: 65) bahwa berita merupakan laporan tercepat mengenai fakta yang terbaru, fakta yang menarik atau penting bagi khalayak, dan berita ini dimuat di media berkala seperti surat kabar, radio, televisi, atau media on line. Khusus untuk vlog Yossie-Dani konten-kontenya baru namun wilayah pemberitaannya lokal, hanya sekitar Kota Semarang yang dipublikasikan di media on line (youtube).

Karena ringan dan berimbang antara berita yang informatif dan unsur hiburannya, maka informasi yang ada dalam vlog Yossie-Dani tidak memiliki kedalaman informasi, dan tidak terlalu detail. Karena vlog Yossie-Dani hanya memberikan informasi untuk memberikan awareness masyarakat mengenai keberadaan topik masalah yang diinformasikan.

Hal ini ditujukan agar masyarakat yang telah mengetahui keberadaan informasi dalam vlog Yossie-Dani sehingga masyarakat dapat memberikan respons secara langsung, dan dapat mengubah perilaku masyarakat untuk memanfaatkan program, kegiatan, wisata baru, dan sebagainya yang telah dikonstruksikan melalui vlog "Yossie-Dani." Secara garis besar, tujuan berita dari konten vlog "Yossie-Dani" ialah agar masyarakat dapat mengetahui dan berkontribusi sesuai dengan keahliannya, baik langsung maupun tidak langsung mengenai program, kegiatan, dan wisata baru di Kota Semarang.

$V \log$ "Yossie-Dani" memiliki beberapa aspek nilai dalam berita yang terkandung di dalam konten vlog "Yossie-Dani”" dalam menyampaikan informasi kepada masyarakat Kota Semarang. Aspek nilai dalam vlog "Yossie-Dani", yaitu:

Konten vlog "Yossie-Dani" memiliki kebaruan informasi resmi yang dapat dimanfaatkan publik Kota Semarang. Maksud kebaruan di sini ialah konten- 
Analisis Pemanfaatan Vlog "Yossie-Dani” dalam Penyampaian Informasi Publik Pemerintah Kota Semarang

kontennya belum pernah dipublikasikan oleh media lain, atau vlogger lain. Dengan kebaruan ini membuat penonton atau masyarakat merasa mendapatkan sesuatu yang baru, sehingga tidak membosankan. Prinsip kerja media massa dipakai oleh tim kreatif vlog, yaitu selalu menyajikan sesuatu yang aktual. Dengan demikian membuat masyarakat Kota Semarang menunggu-nunggu informasi terbarunya.

Konten atau berita vlog Yossie-Dani juga bermanfaat, penting, dan sesuai dengan kebutuhan masyarakat Kota Semarang. Dengan berita yang penting dan bermanfaat untuk masyarakat, sehingga masyarakat terus mengikuti perkembangan dari konten ke konten yang dishare ke youtube. Bahkan tidak sedikit informasi yang di vlog ini menjadi pedoman atau pentunjuk masyarakat dalam melakukan aktivitas, mengikuti program pemerintah di mana masyarakat bisa ikut terlibat aktif, petunjuk ketika masyarakat mau melakukan urusan dengan dinas-dinas terkait di Kota Semarang. Kehadiran vlog ini pun bisa membantu masyarakat memahami komunitas tempat tinggalnya, yang berarti bahwa informasi yang ditujukan kepada masyarakat Kota Semarang yang sesuai dengan kebiasaan masyarakat Kota Semarang

Di antara nilai berita yang menjadi standar konten $v$ log ialah menghadirkan narasumber atau para pejabat yang popular di masyarakat, mulai dari pejabatpejabat publik, tokoh masyarakat dan orang-orang yang berpengaruh lainnya di Kota Semarang. Kehadiran narasumber ini tidak ada di setiap konten, tetapi dihadirkan disesuaikan dengan tema dari konten, biar kontennya lebih berbobot.

Kemudian beritanya mengandung emosi dan kedekatan jarak (proximity), maksudnya ada kedekatan secara emosional terhadap isu yang sedang berlangsung dalam waktu tertentu. Misalnya tentang kuliner kegiatan masyarakat Kota Semarang, maka masyarakat Kota Semarang akan antusias untuk menonton dan mengikutinya terus.

Beberapa nilai berita dari vlog Yossie-Dani sama dengan nilai berita yang dijelaskan Wendratama (2017: 38) di antaranya, kebaruan (aktual), berpengaruh, relevan, konflik, popularitas, emosi, ketidakwajaran, dan kedekatan jarak. Namun dalam berita vlog, tidak memiliki unsur konflik dan ketidakwajaran. Karena tim kreatif vlog sangat menghindari kontroversi atau pemberitaan yang bisa memicu konflik. Malah sebaliknya, konten-konten yang dibuat agar bisa meningkatkan keharmonisan, gotong royong, saling membantu, dan hidup rukun berdampingan.

Nilai berita lainnya di $v \log$ "Yossie-Dani" ialah informasi yang bersifat fakta dan dapat dipertanggungjawabkan karena konten vlog "Yossie-Dani" merupakan salah satu bentuk media penyampaian informasi yang dimiliki langsung oleh instansi Pemerintah Kota Semarang. Berita yang disampaikan harus bersifat fakta dan benar bukan memuat opini dari sumber berita. Kebenaran atau fakta ini bersifat mutlak (Wendratama, 2017: 38). 
Vlog Yossie-Dani memperjuangkan informasi yang adil dan netral. Tidak ada keberpihakan atas informasi yang disampaikan untuk saling menjatuhkan pihak-pihak lainnya, demi mendapatkan keuntungan pribadi. Sekalipun vlog ini milik pemerintah, dikelola oleh pemerintah, tetapi dalam pelaksanaannya vlog ini tetap berada pada posisi yang netral yaitu tidak berpihak pada satu pihak, dan menyajikan informasi yang adil.

Konten apa pun yang dipublikasikan di vlog Yossie-Dani selalu benar adanya, tidak mengarang dan dramatisasi yang bisa membohongi masyarakat. Dengan seperti ini, masyarakat tidak hanya mendapatkan informasi langsung dari para pejabat pemerintah, tetapi juga berita yang terpercaya (Wendratama, 2017: 38). Upaya ini dapat mengurangi isu hoaks yang beredar di masyarakat (Besman, et al., 2018).

Adapun cara yang dilakukan tim vlog agar bisa menghadirkan fakta dan benar-benar teruji faktanya dalam berita atau konten-konten di vlognya, ialah dengan cara mendapatkan data langsung dari sumbernya atau pihak yang berkaitan dalam kegiatan atau program acara, sehingga dapat dipastikan bahwa data yang disebarluaskan diolah, kemudian dijadikan informasi yang memiliki validitas tinggi.

Berdasarkan paparan nilai berita vlog Yossie-Dani, menurut Wendratamaada yang kurang dari nilai berita tersebut, yaitu fokus (2017: 38). Berita harus fokus dan dapat menjelaskan judul, topik bahasan, bahasa, tujuan dan manfaat, tidak memberikan arah penulisan atau video yang melebar, sehingga informasi yang diberikan akan terfokus.

Konten vlog "Yossie-Dani" dalam menyampaikan informasi kepada publik mengandung unsur $5 \mathrm{~W}+1 \mathrm{H}$. Unsur ini merupakan rumus berita yang sudah baku dan dipakai disetiap wartawan dalam membuat berita hasil liputannya. Rumus ini memandu wartawan ketika meliput dan membuat berita (Wendratama, 2017: 38). Dalam berita harus memuat jawaban yang mengandung unsur What (apa peristiwanya), Who (siapa korban atau pelakunya), When (kapan kejadiannya), Where (di mana kejadiannya), Why (kenapa sampai terjadi), How (bagaimana kejadiannya). Seandainya berita tersebut tentang bencana atau kecelakaan.

\section{PENUTUP}

Pemerintah Kota Semarang menyadari betul betapa pentingnya menggunakan media sosial sebagai media publikasi informasi seputar pemerintahan yang bermanfaat untuk masyarakat., karena masyarakat saat ini sudah mulai beralih ke media baru (new media), jadi akan ketinggalan jika tetap menggunakan media konvensional.

Pemerintah Kota Semarang lebih memilih youtube dan vlog sebagai media barunya yang bisa membantu dalam penyampaian informasi pada masyarakat 
Analisis Pemanfaatan Vlog "Yossie-Dani” dalam Penyampaian Informasi Publik Pemerintah Kota Semarang

dikarenakan media tersebut saat ini paling banyak penggunanya, mulai dari kalangan tua sampai muda. Media ini lebih menarik dan bisa membuat interaktif antara pemerintah dengan masyarakat, sehingga bisa meningkatkan hubungan antara kalangan top level dengan lapisan bawah.

Strategi yang digunakan Pemerintah Kota Semarang dalam rangka mengikat komunikasinya dengan masyarakat Semarang dengan membuat konten vlog "Yossie-Dani" yang mengandung aktivitas sehari-hari, hiburan, dan kontenkonten yang dekat dengan kehidupan sehari-hari masyarakat Semarang. Ada beberapa trik dalam vlog nya seperti memanfaatkan konsep blooper, memberikan style editing berupa sound effect, text effect, atau video yang berisi kesalahan selama proses shooting berlangsung.

Meskipun banyak unsur hiburan dan terkesan santai, Pemerintah Kota Semarang senantiasa mempertahankan kualitas konten berita, yaitu dengan menggunakan narasumber yang populer, relevan dengan kehidupan masyarakat, penyampaian informasi berdasarkan fakta terbaru dan informasi dapat dipertanggungjawabkan, jarak kedekatan dengan masyarakat, serta penggunaan rumus $5 \mathrm{~W}+1 \mathrm{H}$.

Media akan terus mengalami perkembangan, dan dampaknya pada kehidupan manusia, terutama cara berkomunikasi antar manusia mengalami pergeseran. Oleh karenanya, penting kiranya untuk terus mengawal perubahanperubahan media komunikasi ini dengan beberapa penelitian. Termasuk di dunia pemerintahan agar kinerja pemerintah terkontrol, juga bisa menemukan formulasi baru yang bisa membantu pemerintah dalam meningkatkan kinerja dan sinergitas antara pemerintah dengan berbagai lapisan masyarakat.

\section{DAFTAR PUSTAKA}

Adi, D. S., \& Mariani, A. (2016). Komunikasi Askriptif Tokob Publik Untuk Mencegah Kegiatan Seks Komersial Terselubung. Dinamika Global : Rebranding Keunggulan Kompetitif Berbasis Kearifan Lokal, (Prodi Manajemen Fakultas Ekonomi dan Bisnis Universitas Jember), 539-553. https://doi.org/https://jurnal.unej.ac.id/index.php/prosiding/article/vie $\mathrm{w} / 3700$.

APJII. (2017). Penetrasi \& Perilaku Pengguna Internet Indonesia Tahun 2017 alam APJII (Vol. 2018).

Andriana, N. (2013). Media Siber Sebagai Alternatif Jembatan Komunikasi Antara Rakyat dan Pemimpinnya. Jurnal Penelitian Politik, 10 (2), 79-93.

Aqil, M. R., \& Fahri, M. (2018). Vlogging as a Medium for Eighth Graders of SMP Negeri 1 Gresik in Speaking Recount Text Mohammad Robith Aqil. Retain, 6 (2), 186-194.

Baskoro, A. (2009). Panduan Praktis Searching di Internet. Jakarta Selatan: Media Kita. 
Besman, A., Adiputra, A. V., \& Saputra, S. J. (2018). President Joko Widodo Communication in the \#Baliaman Vlog. Jumal Penelitian Komunikasi, 21 (1), 43-56. https://doi.org/10.20422/jpk.v21i1.518.

David, E. R., Sondakh, M., \& Harilama, S. (2017). Pengaruh Konten Vlog dalam Youtube terhadap Pembentukan Sikap Mahasiswa Ilmu Komunikasi Fakultas Ilmu Sosial dan Politik Universitas Sam Ratulangi. Jurnal Acta Diurna, 6 (1).

Earnshaw, R. (2017). State of the Art in Digital Media and Applications. https://doi.org/10.1007/978-3-319-61409-0.

Gannon, V., \& Prothero, A. (2018). Beauty bloggers and You'Tubers as a community of practice. Journal of Marketing Management, 34 (7-8), 592-619. https://doi.org/10.1080/0267257X.2018.1482941.

Gibson, M. (2016). YouTube and bereavement vlogging: Emotional exchange between strangers. Journal of Sociology, 52 (4), 631-645. https:/ / doi.org/10.1177/1440783315573613.

Graham, M., \& Avery, J. E. (2013). Government Public Relations and Social Media: An Analysis of the Perceptions and Trends of Social Media Use at the Local Government Level, 7(4), 1-21.

Hendricks, J. A., \& Robert E. Denton, J. (2010). Political Campaigns and Communicating with the Electorate in the Twenty-First Century. In J. A. Hendricks \& R. E. Denton (Eds.), Communicator In Chief: How Barack Obama Used New Media Technology to Win the White House (pp. 1-18). Estover Road, Plymouth: Lexington Books.

Haryanto, A. T. (2018). 130 Juta Orang Indonesia Tercatat Aktif di Medsos. Retrieved March 24, 2019, from https://inet.detik.com/cyberlife/d-3912429/130juta-orang-indonesia-tercatat-aktif-di-medsos.

Herman. (2017). Strategi Komunikasi Pengelolaan Zakat, Infak, dan Sedekah (ZIS) Melalui Media Sosial. Communicatus: Jumal Ilmu Komunikasi, 1(2), 171-190. DOI: 10.15575/cjik.v1i2.4833.

Irawan. (2009). Kamus Istilah Komputer Untuk Orang Awam. Palembang: Maxikom. Jakpat. (2018). Watching Vlog. Retrieved from http://jajakpendapat.net/pdf/14917/watching-vlog-jakpat-free-survey report.

Izzah, L., \& Hadi, M. S., (2018). Pembelajaran Introduction To Linguistics Melalui Vlog. dalam prosiding Seminar Nasional Pendidikan Era Revolusi "Membangun Sinergitas dalam Penguatan Pendidikan Karakter pada Era IR 4.0”. Jakarta: Universitas Muhammadiyah.

Liu, M. T., Liu, Y., Zhang, L. L., Liu, M. T., Liu, Y., \& Zhang, L. L. (2019). Vlog and brand evaluations: the influence of parasocial interaction. https://doi.org/10.1108/APJML-01-2018-0021.

Mahameruaji, J. N., Puspitasari, L., Rosfiantika, E., \& Rahmawan, D. (2018). 
Analisis Pemanfaatan Vlog "Yossie-Dani” dalam Penyampaian Informasi Publik Pemerintah Kota Semarang

Bisnis Vlogging dalam Industri Media Digital di Indonesia. Jurnal Ilmu Komunikasi, 15 (1), 61-74. https://doi.org/10.24002/jik.v15i1.1007.

Mardiana. (2018). Pengaruh Media Sosial terhadap Tingkat Pidana Narkotika di Sulawesi Tenggara. Communicatus: Jurnal Ilmu Komunikasi. 2 (2): 109-122. DOI: 10.15575/cjik.v2i2.3659.

Martinus, H., \& Chaniago, F. (2017). Analysis Of Branding Strategy Through Instagram With Storytelling In Creating Brand Image On Proud Project. Humaniora, $\quad 8 \quad$ (3) $\quad$ : https://doi.org/https://doi.org/10.21512/humaniora.v8i3.3678.

Morrisan. (2019). Riset Kualitatif. Jakarta: Prenada Media Group.

Muhammad, A. (2017). Komunikasi Organisasi. Jakarta: Bumi Aksara.

Nasrullah, R. (2015). Media Sosial Prosedur, Tren, dan Etika. Bandung: Simbiosa Rekatama Media.

Nasrullah, R. (2014). Teori dan Riset Media Cyber (Cybermedia). Jakarta: Penerbit Kencana.

Panuju, R. (2018). Pengantar Studi Ilmu Komunikasi Komunikasi sebagai Kegiata Komunikasi sebagai Ilmu. Jakarta: Prenadamedia Group.

Prastowo, A. (2011). Memahami Metode-Metode Penelitian Suatu Tinjauan Teoretis dan Praksis. Jogyakarta: Ar-Ruzz Media.

Priana, R. Y. S. (2017). Pemanfaatan Vlog sebagai Media Pembelajaran Teritegrasi Teknologi Informasi. Dalam Prosiding Seminar Nasional Pendidikan FKIP UNTIRTA, 313-316.

Purwadi, P., Novianty, A., Deden, N., Lestari, Y. (2017). Local Tourism Promotion through Multilingual Vlog in Garut, Indonesia. The 5th Asian Academic Society International Conference, 1-5. https://doi.org/http://aasic.org/proc/aasic/article/view/303.

Raby, R., Caron, C., Théwissen-LeBlanc, S., Prioletta, J., \& Mitchell, C. (2018). Vlogging on YouTube: the online, political engagement of young Canadians advocating for social change. Journal of Youth Studies, 21(4), 497514. https://doi.org/10.1080/13676261.2017.1394995.

Sari, R. P. (2018). Representasi Identitas Perempuan dalam Video Blog sebagai Budaya Anak Muda (Studi Semiotika Vlog Gitasav di Youtube). AJIE Asian Journal of Innovation and Entrepreneurship. 03 (02), 157-167.

Schmittauer, A. (2017). Vlog Like a Boss. Jakarta: Kompas Gramedia.

Sugiono, S. dan Irwansyah (2019). Vlog sebagai Media Storytelling Digital Bagi Tokoh Publik Pemerintahan. Jurnal Studi Komunikasi dan Media. 23 (2), $115-134$.

Sumadiria, H. (2017). Jurnalistik Indonesia : Menulis Berita Dan Feature, Panduan Praktis Jurnalis Professional. Cet. Ke-3. Bandung: Simbiosa Rekatama.

Wendratama, E. (2017). Panduan Membuat Konten Online yang Berkualitas dan 
Martha Tri Lestari \& Lisa Aji Sasmita

Menarik. Yogyakarta: Bentang Pustaka.

Wolf, M., Sims, J., \& Yang, H. (2018). Social media? What social media? Annual Conference of the UK Academy for Information Systems. Oxford.

Wulansari, I. (2014). Artikulasi Komunikasi Politik Ridwan Kamil dalam Media Sosial Twitter. Ultimacomm: Jurnal Ilmu Komunikasi, 6 (2), 20-40. https://doi.org/https://doi.org/https://doi.org/10.31937/ultimacomm.v 6i2.413.

Gumelar, R. G. (2013). Konvergensi Media Online. Lontar Jurnal Ilmu Komunikasi, 2 (2), 6-14. 